\title{
Speciation of Aluminum in Soil Extracts Using Cation and Anion Exchangers Followed by a Flow-Injection System with Fluorescence Detection Using Lumogallion
}

\author{
Etsu Yamada, ${ }^{* * * *}$ Takayuki Hiwada, ${ }^{* *}$ Takashi InABA,** Motoaki ToKUKURA,** and Yasuro FusE* \\ * Center for Environmental Science, Kyoto Institute of Technology, \\ Matsugasaki, Sakyo-ku, Kyoto 606-8585, Japan \\ **Department of Chemistry and Material Technology, Kyoto Institute of Technology, \\ Matsugasaki, Sakyo-ku, Kyoto 606-8585, Japan
}

\begin{abstract}
Flow-injection analysis (FIA) with fluorescence detection of aluminum using lumogallion was applied to the chemical speciation of aluminum in soil extracts after the separation of aluminum species with ionic exchangers. Aluminum complexes with organic substances (anion species) can be specified from other species by using a strongly acidic cation exchanger in the $\mathrm{pH}$ range of 3 to 5. Furthermore, aluminum can be separated into three categories, namely, (i) the $\mathrm{Al}^{3+}$ and $\mathrm{Al}-\mathrm{OH}$ complex, (ii) aluminum organic complexes (cation species), and (iii) its anion species by using a strongly acidic and a weakly acidic cation exchanger at around $\mathrm{pH}$ 5. A considerable percentage of water-soluble aluminum in soils was found to be complexes with humic substances.
\end{abstract}

(Received March 4, 2002; Accepted May 15, 2002)

\section{Introduction}

Recently, acid rain has received great attention as a global environmental problem because of the effect of acidic deposition within various ecosystems. ${ }^{1,2}$ The decline of Japanese cedar and pine trees has been frequently reported in Japan. ${ }^{3-5}$ Therefore, the role of air pollutants, such as atmospheric $\mathrm{NO}_{2}, \quad \mathrm{SO}_{2}, \mathrm{O}_{3}$, and $\mathrm{H}_{2} \mathrm{O}_{2}$, influencing the biogeochemical cycles in mountains or forests and the effect of $\mathrm{H}_{2} \mathrm{O}_{2}$ and $\mathrm{O}_{3}$ on the oxidation of $\mathrm{SO}_{2}$ in rainwater have been investigated. ${ }^{6-9}$ Based on the acidity and chemical properties of soils, it is suggested that the acid-buffering capacity of the soils of mountains on three sides of the Kyoto basin will considerably decrease in the near future, as indicated by the soil $\mathrm{pH}$ as well as the concentrations of exchangeable calcium and magnesium, exchangeable aluminum, and sulfate in the soils. ${ }^{10,11}$ Although aluminum has been thought to be virtually non-toxic for many years, a recent study has revealed its poisonous nature. Moreover, the differential toxicity of various aluminum species to aquatic and terrestrial organisms has been demonstrated. ${ }^{12-14}$ In particular, it is important to clarify the behavior and speciation of aluminum in soil and aquatic systems because the toxic effect of mobile aluminum on trees is thought to be one of the causes for forest decline in some areas of Europe, such as southern Germany..$^{15}$

The chemical speciation of aluminum is still very difficult, even using modern instrumental techniques, mainly because the concentration of aluminum in environmental samples is usually very low and the chemistry of aluminum is rather complicated. Thus, experimental approaches to this problem seem to be

$\dagger$ To whom correspondence should be addressed.

E-mail: eyamada@ipc.kit.ac.jp limited at present. ${ }^{16,17}$ High-performance cation-exchange chromatography with fluorescence detection of the aluminumlumogallion complex has been applied to the chemical speciation of aluminum in natural water ${ }^{18,19}$ and soil solutions. ${ }^{20}$ A relatively high concentration of calcium ion was necessary to elute aluminum. Tsunoda et al. have applied cation-exchange and size-exclusion high-performance liquid-chromatographic methods with postcolumn fluorescence detection using 5-sulfo8 -quinolinol to the chemical speciation of aluminum in soilextract samples. ${ }^{17}$ It was reported that the dissociation of aluminum organic complexes on the column was not observed because aluminum ion is relatively inert against a ligandexchange reaction. However, it was found that the dissociation of the aluminum complex with fulvic acid easily occurred at around $\mathrm{pH} 3$.

Thus, in this study, the separation of aluminum species was studied using cation and anion exchangers without changing the $\mathrm{pH}$ and/or ionic strength of the sample solutions. Flowinjection analysis (FIA) with the fluorescence detection of aluminum using lumogallion was investigated and applied to the chemical speciation of aluminum in soil extracts after the separation of the aluminum species with ionic exchangers. The results were compared with values estimated by equilibrium calculations.

\section{Experimental}

\section{Reagents and apparatus}

A solution of $2.9 \mathrm{mM}$ lumogallion was prepared with lumogallion (Dojin Chemical, Kumamoto, Japan) in distilled water and diluted before use. This solution was kept in a refrigerator for one month. An aluminum(III) atomicabsorption standard (1000 $\mathrm{mg} \mathrm{dm}^{-3}$ ) (Wako Pure Chemicals, 


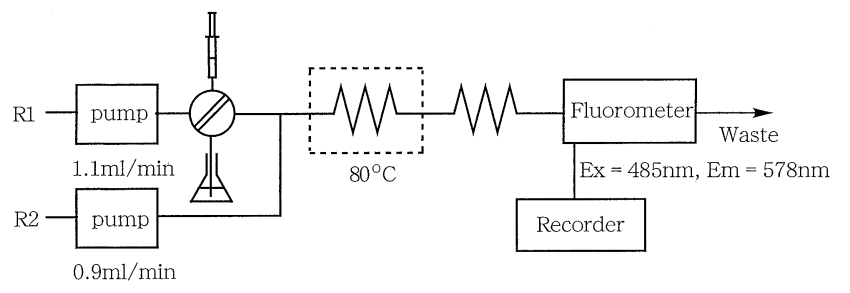

Fig. 1 FIA system for measuring aluminum with lumogallion. R1, $26 \mathrm{mM} \mathrm{CH} \mathrm{CHOH}_{3}-26 \mathrm{mM} \mathrm{CH} \mathrm{CH}_{3} \mathrm{COONa}(\mathrm{pH} \mathrm{5})$; $\mathrm{R} 2,87 \mu \mathrm{M}$ lumogallion solution.

Osaka, Japan) was used as a stock standard. A buffer solution of $26 \mathrm{mM}$ acetic acid-26 mM sodium acetate was prepared by diluting $1 \mathrm{~N}$ acetic acid-1 $\mathrm{N}$ sodium acetate solution ( $\mathrm{pH}$ 5) with distilled water before use. Humic acid (Aldrich Chemicals, extracted from peat soil) was purified by the repeated dissolution in $0.1 \mathrm{M}$ sodium hydroxide and precipitated in 0.1 M hydrochloric acid until the color of the supernatant solution was eliminated. ${ }^{21}$ Humic and fulvic acids obtained from the Ahorizons of a brown forest soil (Dystric Cambisol, Dando, Aichi, Japan) and an ando soil (Humic Andozol, Inogashira, Shizuoka, Japan), which were prepared by the IHSS (International Humic Substances Society) method and supplied by the Japan Humic Substances Society, were used without purification. ${ }^{22}$ All other chemicals were of the best commercial grade available.

A schematic diagram of the FIA system is shown in Fig. 1. Sample solutions $\left(100 \mathrm{~mm}^{-3}\right)$ were introduced into the line of the buffer solution through a sample injector (Rheodyne 7125) with a polypropyrene microsyringe, and mixed with an $87-\mu \mathrm{M}$ lumogallion solution. They were reacted in a mixing coil $(3 \mathrm{~m}$ $\times 0.5 \mathrm{~mm}$ i.d.) at $80^{\circ} \mathrm{C}$ in a water bath and then maintained in a cooling coil $(2.5 \mathrm{~m} \times 0.5 \mathrm{~mm}$ i.d.). The fluorescence was monitored with a Shimadzu RF-550 fluorescence detector at Ex $=485 \mathrm{~nm}$ and $\mathrm{Em}=578 \mathrm{~nm}$. A National VP-6513A recorder was used. The flow rates of the buffer solution and the lumogallion solution were $1.1 \mathrm{ml} / \mathrm{min}$ and $0.9 \mathrm{ml} / \mathrm{min}$, respectively

Ultrafiler membranes (Millipore ultrafree-C3 centrifugal filter, available at 3000, 5000, 10000, 30000 and 100000 molecular weights) were used to fractionate the aluminum species and humic substances by a centrifuge (Millipore Tibitan).

\section{Preparation of soil extracts ${ }^{10}$}

Soil samples were collected at 5 sampling points on Mt. Hiei. These samples were dried at $35^{\circ} \mathrm{C}$ in a steam oven for 2 days and then passed through a $2 \mathrm{~mm}$ non-metallic filter. Soil extractants were prepared according to the standard soilanalysis method. After $50 \mathrm{ml}$ of distilled water had been added to $10 \mathrm{~g}$ of the soil sample, the mixture was vigorously shaken with a mechanical shaker for $1 \mathrm{~h}$ and immediately passed through a $5 \mathrm{C}$ filter. The supernatant solution was then passed through a $0.2 \mu \mathrm{m}$ membrane filter (Millipore) and applied to an analysis for Al. This fraction extracted into distilled water was defined as "water-soluble Al".

Speciation of aluminum in soil extracts using cation and anion exchangers

A strongly acidic cation exchanger with a sulfopropyl group on a polymer base (Tosoh Toyopak IC-SP) and a weakly acidic cation exchanger with an ethylcarboxyl group on a polymer
Table 1 Permissible amount of coexisting substances for aluminum determination

\begin{tabular}{cc}
\hline Coexisting substance & $\begin{array}{c}\text { Permissible amount } \\
\text { [Coexisting substance]/[A1] }\end{array}$ \\
\hline $\mathrm{Fe}^{3+}$ & 200 \\
$\mathrm{~F}^{-}$ & 20 \\
$\mathrm{Cl}^{-}$ & 1000 \\
$\mathrm{Citric} \mathrm{acid}^{\text {Fulvic acid }}$ & 200 \\
\end{tabular}

The followings are tolerable (excess, $\times 1000$ ): $\mathrm{Na}^{+}, \mathrm{K}^{+}, \mathrm{Ca}^{2+}, \mathrm{Mg}^{2+}$, $\mathrm{NH}_{4}{ }^{+}, \mathrm{SO}_{4}{ }^{2-}, \mathrm{NO}_{3}{ }^{-}$.

Al: $5 \mathrm{ppb}$.

base (Varian Bond Elut CBA) were used as cation exchangers. On the other hand, a strongly basic anion exchanger with a trimethylaminopropyl group on a polymer (Varian Bond Elut $\mathrm{NH} 2$ ) and a weakly basic anion exchanger with a diethylaminoethyl (DEAE) group on a polymer gel (Tosoh Toyopak DEAE) were used as anion exchangers. All exchangers were washed with distilled water before use. One milliliter of the aluminum solution in the absence or presence of oxalic acid, malic acid, humic acid or fulvic acid was passed through each exchanger with a polypropyrene syringe. The aluminum concentration in the effluent was determined by the FIA method with lumogallion after adjusting to $\mathrm{pH} 3$ with $\mathrm{HCl}$. The results were compared with the estimated values by an equilibrium calculation.

Speciation of water-soluble aluminum in soil extracts was carried out using two kinds of cation exchangers. When the soil $\mathrm{pH}$ was in the range of 3 to 5 , the aluminum complex with the organic substance (anion species) was separated from other species using a strongly acidic cation exchanger. When the soil $\mathrm{pH}$ was in the range of 4.5 to 5.5, the $\mathrm{Al}^{3+}$ and $\mathrm{Al}-\mathrm{OH}$ complex, an aluminum complex with an organic substance (the cation species), and its anion species were specified by using two kinds of cation exchangers. Furthermore, the fluorescence of humic substances in soil extracts was measured by Shimadzu RF-5300PC fluorescence spectrophotometry at Ex $=340 \mathrm{~nm}$ and $\mathrm{Em}=435 \mathrm{~nm}$, and its concentration was determined by a calibration curve of standard fulvic acid (Dando).

\section{Equilibrium calculations}

Estimates of aluminum species were made using a chemicalequilibrium program for personal computers that we had developed. The stability constants of the aluminum species were used in previous papers. ${ }^{17}$

\section{Results and Discussion}

Determination of aluminum by the FIA method with lumogallion The optimum conditions for the determination of aluminum in environmental samples by the FIA method with lumogallion were investigated and compared with those by the batch method. The concentration of lumogallion was increased from $29 \mu \mathrm{M}$ to $87 \mu \mathrm{M}$ to prevent interference from other coexisting ligands, such as humic substances and citric acid. A $26 \mathrm{mM}$ acetate buffer solution was used. The temperature of the first mixing coil was maintained at $80^{\circ} \mathrm{C}$ in a water bath because a bubble was formed above $90^{\circ} \mathrm{C}$, although the fluorescence intensity of Al-lumogallion increased along with an increase of the temperature. Furthermore, it was found that the $\mathrm{pH}$ of the 

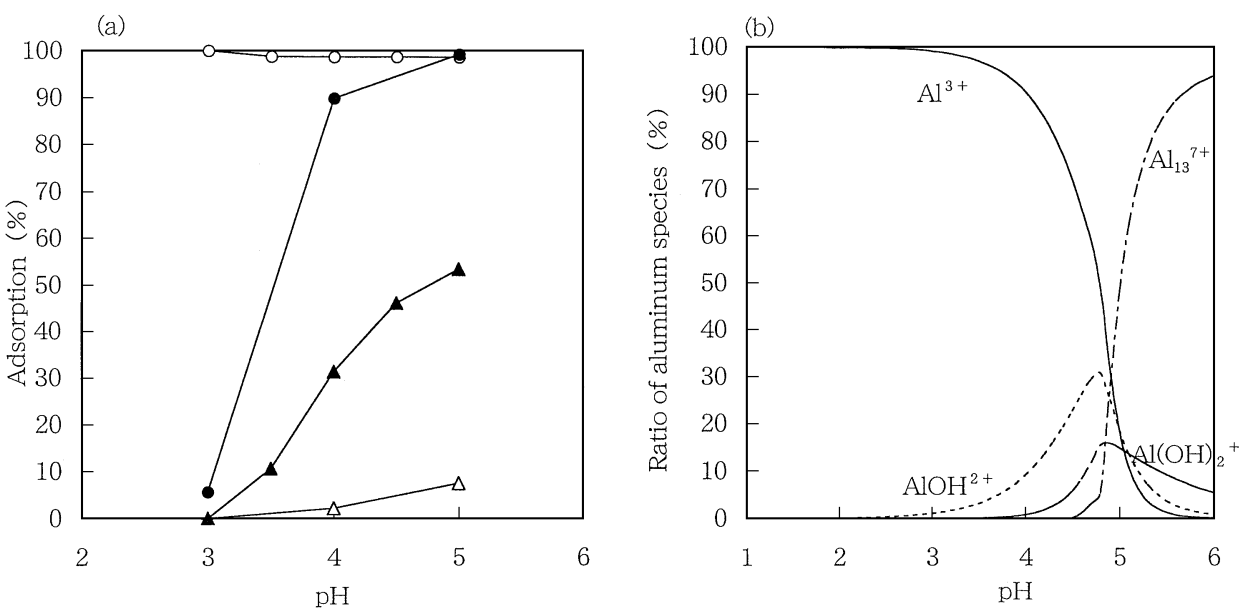

Fig. 2 Adsorption behaviors of aluminum in the absence of coexisting ligands on four kinds of ionic exchangers (a); the ratios of aluminum species calculated by stability constants (b). O, strongly acidic cation exchanger; • weakly acidic cation exchanger; $\Delta$, strongly basic anion exchanger; $\mathbf{\Lambda}$, weakly basic anion exchanger.

sample solution had an important effect on the fluorescence intensity of aluminum with lumogallion because of the adsorption of aluminum on the line at $\mathrm{pHs}$ higher than 3 and the loss of buffering capacity at pHs lower than 3 ; then, the sample solution was measured after adjusting to $\mathrm{pH} 3$ with $\mathrm{HCl}$.

The interference of coexisting substances on the determination of aluminum by the present method was examined (Table 1). $\mathrm{Fe}^{3+}$ and organic substances, such as fulvic acid and citric acid, had no interference on the determination of aluminum by the FIA method. The calibration curve of aluminum was linear in the concentration range of $1-50 \mu \mathrm{g} / \mathrm{l}$. The relative standard deviation of $5 \mu \mathrm{g} / \mathrm{l}$ aluminum was $0.95 \%(n=10)$. The measurement time for one sample was about $5 \mathrm{~min}$. The present method was applied to the determination of aluminum in soil extracts. The recovery of aluminum was quantitative when the known amounts of aluminum were added to the soil extracts.

\section{Speciation of aluminum by cation and anion exchangers}

Because humic substances are mixed molecular compounds with molecular weights of hundreds to several hundred thousand, the stability constants of aluminum complexes with humic substances have not been reported. Thus, the speciation of aluminum in the presence of oxalic acid or malic acid instead of humic substances was carried out using several ionic exchangers, and the results were compared with the estimated values by equilibrium calculations.

The adsorption behaviors of an aluminum solution containing no coexisting ligands on four kinds of ionic exchangers in the $\mathrm{pH}$ range of 3 to 5 and the ratios of the aluminum species calculated by stability constants are shown in Figs. 2(a) and (b), respectively. The $\mathrm{Al}-\mathrm{OH}$ complex was formed above $\mathrm{pH} 3$ and three species of $\mathrm{Al}^{3+}, \mathrm{Al}(\mathrm{OH})^{2+}$ and $\mathrm{Al}(\mathrm{OH})_{2}{ }^{+}$were present in the $\mathrm{pH}$ range of 3 to 5 . Aluminum sorbs on a strongly acidic cation exchanger quantitatively, while aluminum does not sorb on a strongly basic anion exchanger. These results are consistent with the equilibrium calculations because aluminum species in the $\mathrm{pH}$ range of 3 to 5 are present as cation species. Aluminum sorbs on a weakly acidic cation exchanger quantitatively above $c a$. $\mathrm{pH} 4$, but the adsorption of aluminum decreases below $c a . \mathrm{pH}$ 4. This may be due to the fact that the ethylcarboxyl group $\left(\mathrm{p} K_{\mathrm{a}}=4.8\right)$ is not dissociated below about
$\mathrm{pH}$ 4.0. On the other hand, the adsorption of aluminum on a weakly basic anion exchanger gradually increases at $\mathrm{pH}$ values higher than 3, and is about $50 \%$ at $\mathrm{pH}$ 5. This may be attributed to the adsorption of the Al-OH complexes on a weakly basic anion exchanger.

Furthermore, the adsorption behaviors of aluminum in the presence of organic substances $\left(\mathrm{L}^{2-}\right)$, such as oxalic acid $\left(\mathrm{OXL}^{2-}\right)$ or malic acid $\left(\mathrm{MAL}^{2-}\right)$, on four kinds of ionic exchangers in the $\mathrm{pH}$ range of 3 to 5 were investigated and compared with the results calculated by stability constants. The adsorption percentages of an aluminum solution containing various amounts of oxalic acid on a strongly acidic cation exchanger and a strongly basic anion exchanger are shown in Figs. 3(a) and (b), respectively. The adsorption of aluminum on a strongly acidic cation exchanger decreases along with an increase in the concentration of oxalic acid, while that on a strongly basic anion exchanger increases. Aluminum species in the $\mathrm{pH}$ range of 3 to 5 are determined by formation constants to be six species of the $\mathrm{Al}^{3+}$ and $\mathrm{Al}-\mathrm{OH}$ complex $\left(\mathrm{Al}(\mathrm{OH})^{2+}\right.$, $\left.\mathrm{Al}(\mathrm{OH})_{2}{ }^{+}\right)$and aluminum complexes with oxalic acid $\left(\mathrm{AlOXL}^{+}\right.$, $\left.\mathrm{Al}(\mathrm{OXL})_{2}{ }^{-}, \mathrm{Al}(\mathrm{OXL})_{3}{ }^{3-}\right)$; the aluminum organic complexes (anion species) increase with an increase of the concentration of oxalic acid (Fig. 4). The results of aluminum adsorption on a strongly basic anion exchanger are almost consistent with the ratios of the anion species $\left(\mathrm{Al}(\mathrm{OXL})_{2}{ }^{-}, \mathrm{Al}(\mathrm{OXL})_{3}{ }^{3-}\right)$ determined by equilibrium calculations (Table 2 ). Similar results were obtained in the presence of malic acid. These results suggest that aluminum organic complexes (anion species, $\mathrm{AlL}_{2}^{-}$and $\mathrm{AlL}_{3}{ }^{3-}$ ) can be specified by using a strongly acidic cation exchanger or a strongly basic anion exchanger.

The adsorption behaviors of aluminum solutions containing known amounts of oxalic acid or malic acid on two kinds of

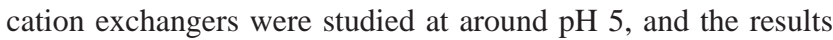
were compared with values estimated by equilibrium calculations. The effect of the $\mathrm{OXL}^{2-}$ concentration on the adsorption of aluminum with these cation exchangers was investigated (Fig. 5). The aluminum adsorption on a strongly acidic cation exchanger was higher than that on a weakly acidic cation exchanger, and its difference was largest at $37 \mu \mathrm{M}$ of oxalic acid. The difference between the adsorption percentage of aluminum on a strongly acidic cation exchanger (A) and that 
(a)

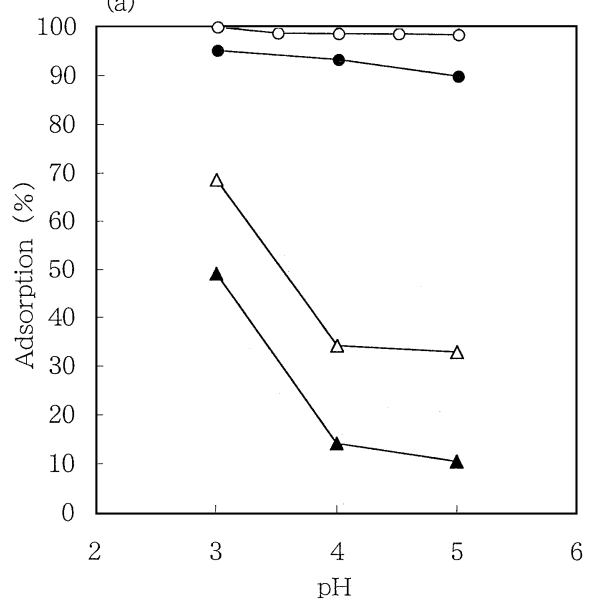

(b)

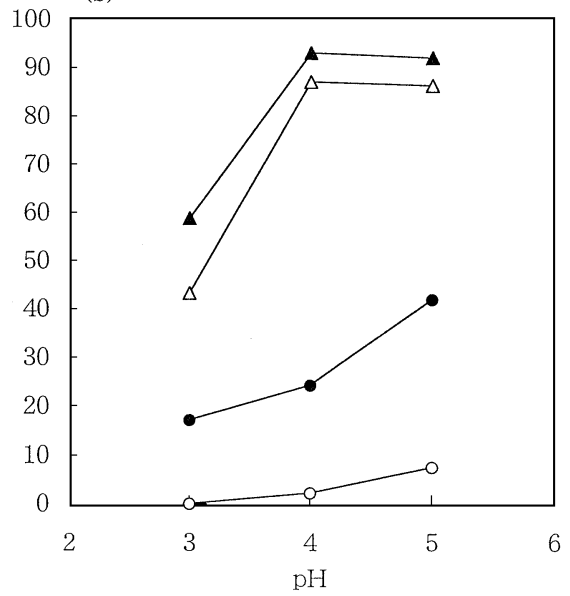

Fig. 3 Adsorption percentages of an aluminum solution containing various amounts of oxalic acid on a strongly acidic cation exchanger (a) and a strongly basic anion exchanger (b). [Al] = 1 ppm (37 $\mu \mathrm{M})$, oxalic acid: o, 0 ppm; •, 3.34 ppm $(37 \mu \mathrm{M}) ; \Delta, 6.68 \mathrm{ppm}(74 \mu \mathrm{M}) ; \boldsymbol{\Delta}, 10.02 \mathrm{ppm}(111 \mu \mathrm{M})$.

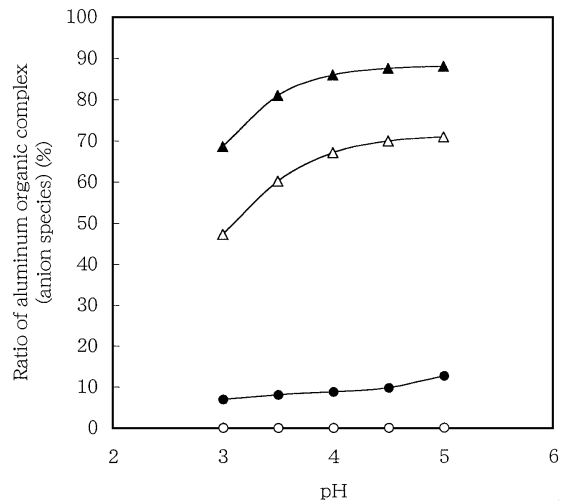

Fig. 4 Ratio of aluminum organic complexes (anion species) by equilibrium calculation. [Al] $=1 \mathrm{ppm}(37 \mu \mathrm{M})$, oxalic acid: $\circ, 0 \mathrm{ppm}$; •, 3.34 ppm $(37 \mu \mathrm{M}) ; \Delta, 6.68$ ppm $(74 \mu \mathrm{M}) ; \boldsymbol{\Lambda}, 10.02$ ppm $(111 \mu \mathrm{M})$.

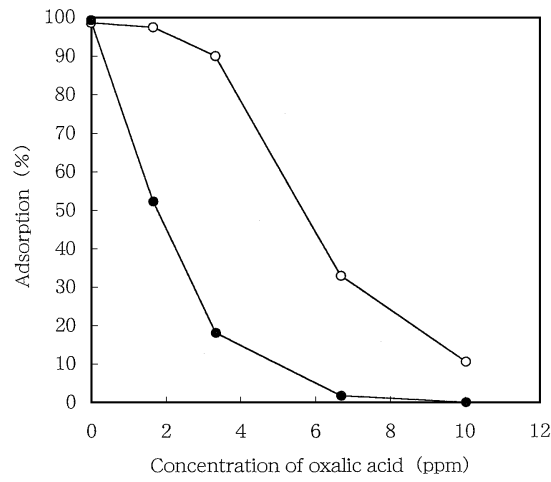

Fig. 5 Effect of the $\mathrm{OXL}^{2-}$ concentration on the adsorption of

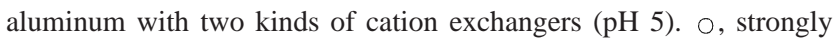
acidic cation exchanger; $\bullet$, weakly acidic cation exchanger. on a weakly acidic cation exchanger (B) and the ratio of aluminum organic complexes (cation species, $\mathrm{AlOXL}^{+}$) by an equilibrium calculation are listed in Table 2. Both results are in good agreement, which means that $\mathrm{AlOXL}^{+}$sorbs on a strongly acidic cation exchanger, but not on a weakly acidic cation exchanger. Similar results were obtained in the presence of malic acid. Thus, the ratio of $\mathrm{AlL}^{+}$in samples can be determined by the difference in the values between (A) and (B) at around $\mathrm{pH} 5$, where the ethylcarboxyl group $\left(\mathrm{p} K_{\mathrm{a}}=4.8\right)$ is dissociated.

From these results, it is considered that aluminum organic complexes (anion species) can be specified from other species by using a strongly acidic cation exchanger or a strongly basic anion exchanger in the $\mathrm{pH}$ range of 3 to 5 . Furthermore, aluminum can be separated into three categories, (i) the $\mathrm{Al}^{3+}$ and Al-OH complex, (ii) aluminum organic complexes (cation species), and (iii) its anion species, by using strongly acidic and weakly acidic cation exchangers at around $\mathrm{pH} 5$.

Speciation of aluminum in the presence of standard humic substances

Since humic substances are present as predominant organic substances in soils, aluminum might be a complex with humic substances. Thus, the present method was applied to the analysis of chemical species of an aluminum solution containing various fulvic or humic acids. Figure 6 shows the effect of the $\mathrm{pH}$ on the ratios of the aluminum complex with Dando fulvic acid (anion species) to the total aluminum. The aluminum complex with Dando fulvic acid (anion species) was formed above $c a . \mathrm{pH} \mathrm{3}$, and its ratio increased with increasing the concentration of fulvic acid. Figure 7 shows the speciation of aluminum (1 ppm) in the presence of Dando fulvic acid (a) and Dando humic acid (b). The ratio of the aluminum complex with fulvic acid (cation species) was largest at $25 \mathrm{ppm}$ of fulvic acid, and decreased above $25 \mathrm{ppm}$ of fulvic acid. The ratio of the aluminum complex with fulvic acid (anion species) increased with an increase of the concentration of fulvic acid, and was smaller than its anion species at $100 \mathrm{ppm}$ of fulvic acid. In the presence of Dando humic acid, the aluminum complex with humic acid (cation species) increased with an increase of the concentration of humic acid, and the ratio was larger than its anion species at even $100 \mathrm{ppm}$ of humic acid. From these results, it is considered that the formation of aluminum complex with Dando fulvic acid may be larger than that with Dando humic acid. When the ratios of aluminum to humic substances were the same, the speciation of aluminum of $0.1 \mathrm{ppm}$ was 


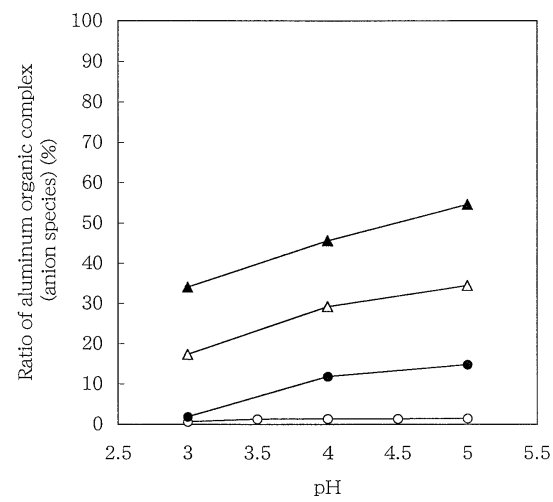

Fig. 6 Effect of the $\mathrm{pH}$ on the ratio of the aluminum complex with Dando fulvic acid (anion species) to total aluminum. Dando fulvic acid: ○, 0 ppm; •, 25 ppm; $\triangle, 50 \mathrm{ppm} ; \mathbf{\Lambda}, 100 \mathrm{ppm}$.
Table 2 Comparison of analysis with ionic exchangers and equilibrium calculation on $\mathrm{Al}^{3+}$ standard solution in the presence of oxalic acid

\begin{tabular}{ccccc}
\hline \multirow{4}{*}{ Oxalic acid/ $\mu \mathrm{M}$} & \multicolumn{3}{c}{ Aluminum species, \% } \\
\cline { 3 - 5 } & & $\begin{array}{c}\mathrm{Al}^{3+} \text { and } \\
\mathrm{Al}^{-O H} \text { complex }\end{array}$ & $\mathrm{AlOXL}^{+}$ & $\begin{array}{c}\mathrm{Al}(\mathrm{OXL})_{2}{ }^{-} \text {and } \\
\mathrm{Al}(\mathrm{OXL})_{3}{ }^{3-}\end{array}$ \\
\hline \multirow{2}{*}{19} & I & 50.0 & 45.0 & 0.5 \\
& II & 50.8 & 47.4 & 1.8 \\
\multirow{2}{*}{37} & I & 16.2 & 71.9 & 11.9 \\
& II & 14.5 & 73.2 & 12.3 \\
\multirow{2}{*}{74} & I & 0.0 & 31.2 & 71.6 \\
& II & 0.4 & 28.1 & 71.5 \\
111 & I & 0.0 & 10.5 & 89.3 \\
& II & 0.0 & 9.7 & 90.3 \\
\hline
\end{tabular}

I: analysis with ionic exchangers, II: equilibrium calculation.
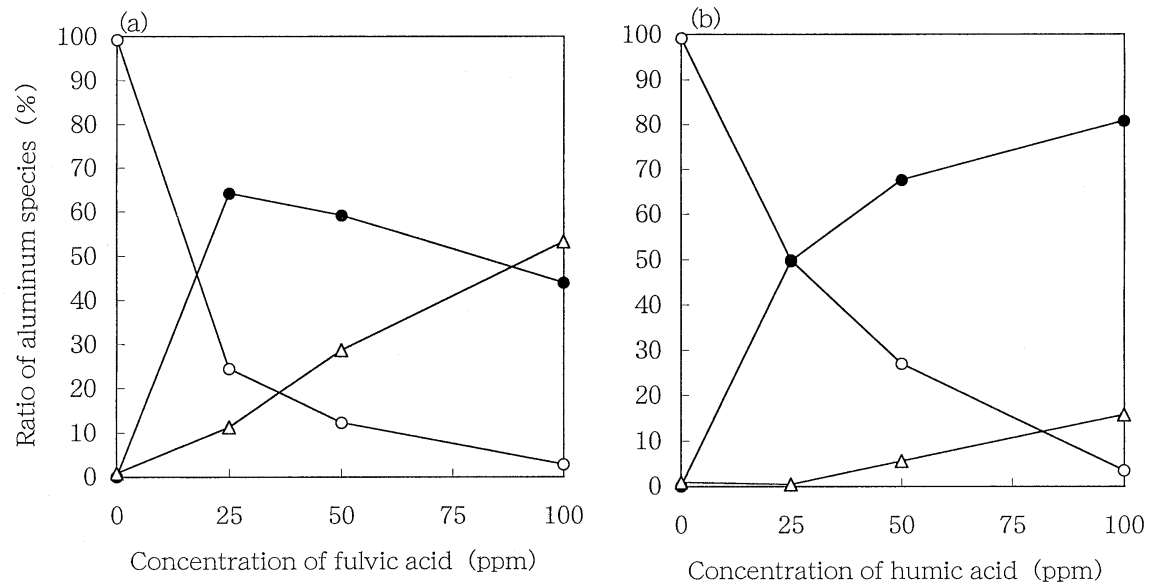

Fig. 7 Speciation of aluminum in the presence of Dando fulvic acid (a) and Dando humic acid (b). $[\mathrm{Al}]=1 \mathrm{ppm}, \mathrm{pH} 5 ; \circ, \mathrm{Al}^{3+}$ and $\mathrm{Al}-\mathrm{OH}$ complex; $\bullet$, aluminum organic complexes (cation species); $\triangle$, aluminum organic complexes (anion species).

similar to that of aluminum of $1 \mathrm{ppm}$. These results suggest that the speciation of aluminum by ionic exchangers is effective to apply to the speciation of aluminum in the presence of humic substances. Figure 8 shows the speciation of aluminum $(1 \mathrm{ppm})$ in the presence of Inogashira fulvic acid (a) and Inogashira humic acid (b). The results in the presence of Inogashira humic substances were almost the same as those in the presence of Dando humic substances. The ratio of the aluminum complex with humic substances (anion species) was higher than its cation species at a high concentration of humic substances, where the ratios of humic substances (ppm) to aluminum (ppm) were in the range of 40 to 90 .

\section{Chemical speciation of aluminum in soil extracts}

The soil $\mathrm{pH}$ and concentrations of water-soluble aluminum and humic substances in soil extracts prepared from soil samples collected at Mt. Hiei in December 1994, 1998, 1999 and 2000 were measured. The relationship between soil $\mathrm{pH}$ $\left(\mathrm{H}_{2} \mathrm{O}\right)$ and water-soluble aluminum concentration in soil extracts is shown in Fig. 9. The water-soluble aluminum in soils was soluble below pH 5. The concentration of water-soluble aluminum in 1994 was much higher than the concentrations in other years. The concentration of humic substances in 1994 was also higher than the concentrations in other years and its trend was clear at lower pHs. The relationship between the concentrations of humic substances and water-soluble aluminum in soil extracts is shown in Fig. 10. The concentration of water-soluble aluminum in soil extracts trended to increase with increasing the concentration of humic substances at the same $\mathrm{pH}$.

Chemical species of aluminum in soil extracts, which were prepared from soil samples collected at Mt. Hiei, were determined by the present method. Figure 11 shows the relationship between the soil $\mathrm{pH}\left(\mathrm{H}_{2} \mathrm{O}\right)$ and the ratio of aluminum organic complexes (anion species). Although the ratios of aluminum organic complexes (anion species) trended to be higher with increasing the soil $\mathrm{pH}$, some of them were relatively high, $40-50 \%$ below soil $\mathrm{pH} 4$. These results may be dependent on the concentration of humic substances in soils. Figure 12 shows the effect of the concentration of humic substances on the ratio of aluminum organic complexes (anion species). The ratio of aluminum organic complexes (anion species) increased with increasing the concentration of humic substances at the same soil $\mathrm{pH}$. The concentration of humic substances in soil extracts, whose ratio of aluminum organic complexes (anion species) was $40-50 \%$ below soil pH 4, was higher than $125 \mathrm{ppm}$. The contribution of humic substances to the formation of aluminum organic complexes might be 

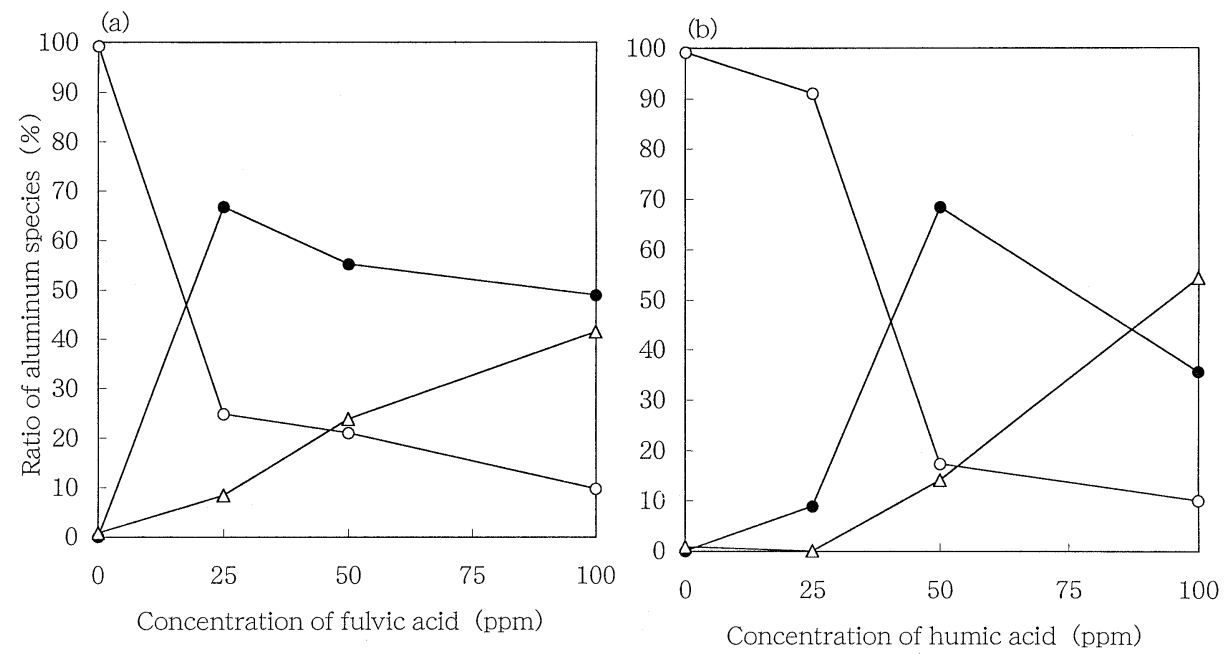

Fig. 8 Speciation of aluminum in the presence of Inogashira fulvic acid (a) and Inogashira

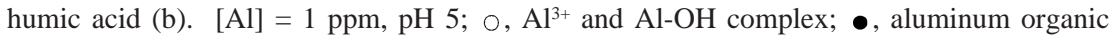
complexes (cation species); $\triangle$, aluminum organic complexes (anion species).

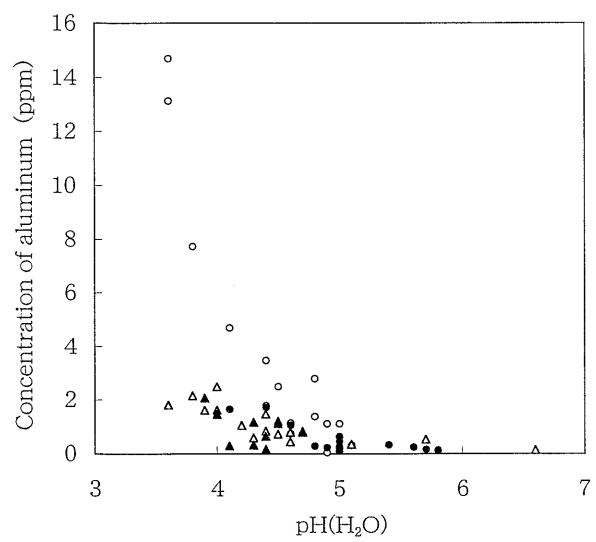

Fig. 9 Relationship between the soil $\mathrm{pH}\left(\mathrm{H}_{2} \mathrm{O}\right)$ and the watersoluble aluminum concentration in soil extracts. O, December 1994;

•, December 1998; $\triangle$, December 1999; ^, December 2000.

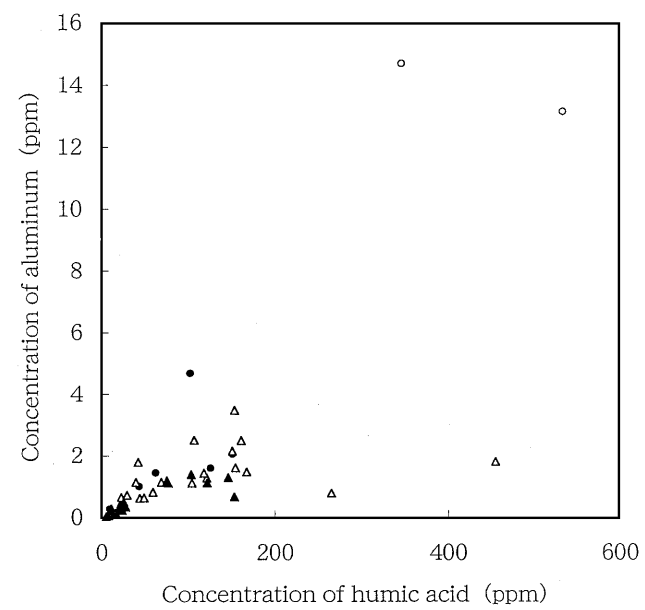

Fig. 10 Relationship between the concentrations of humic substances and water-soluble aluminum in soil extracts. $\mathrm{O}, \mathrm{pH} 3.5$; $\mathrm{pH} 4.0 ; \triangle, \mathrm{pH} 4.5 ; \mathbf{\Delta}, \mathrm{pH} 5.0$.

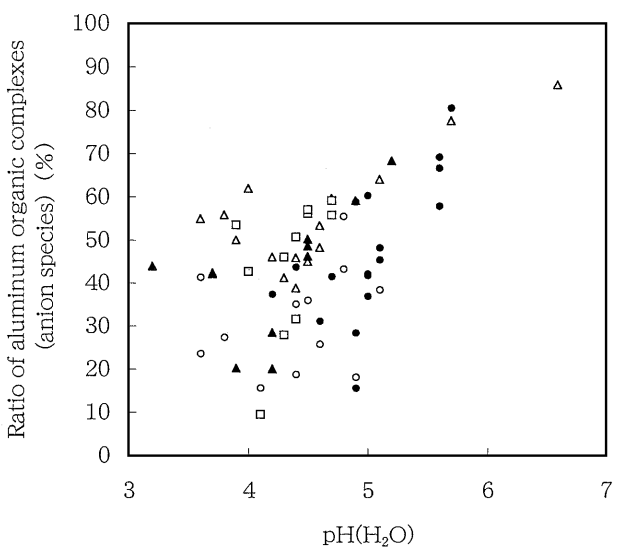

Fig. 11 Relationship between the soil $\mathrm{pH}\left(\mathrm{H}_{2} \mathrm{O}\right)$ and the ratio of aluminum organic complexes (anion species). O, December 1994; December 1998; $\Delta$, December 1999; \, September 2000; December 2000.

possible. In view of Tam and McColl's report concerning the presence of oxalic acid in soil extracts, oxalic acid might be another possibility. ${ }^{23}$ Furthermore, the chemical speciation of aluminum in soil extracts whose $\mathrm{pH}$ was in the range of 4.6 to 5.2 was carried out using two kinds of cation exchangers. The ratio of aluminum species as a function of the concentration of humic substances is shown in Fig. 13. It was found that few $\mathrm{Al}^{3+}$ and $\mathrm{Al}-\mathrm{OH}$ complexes were present, and that aluminum organic complexes were predominant at around $\mathrm{pH}$ 5. The ratio of aluminum organic complexes (anion species) was higher than its cation species at a high concentration of humic substances, where the ratios of humic substances (ppm) to aluminum (ppm) were in the range of 45 to 1185 . These results were consistent with those in the presence of standard humic substances, as stated above. The molecular weights of humic substances in soils at Mt. Hiei were estimated to be in the range of 3000 to over 10000 , as determined by using ultrafilter membranes. The molecular weights of aluminum species in soils at around $\mathrm{pH} 5$, considering that about $90 \%$ of them were complexes with organic substances from the results using ionic exchangers, were also determined by fractionation with ultrafilter 


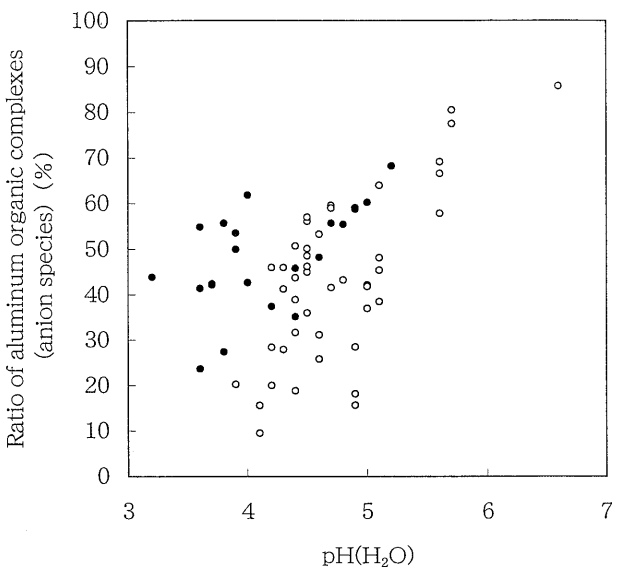

Fig. 12 Effect of the concentration of humic substances on the ratio of aluminum organic complexes (anion species). Humic substances:

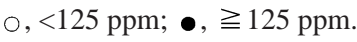

membranes. Almost all of them were estimated to be above 10000. Thus, a considerable percentage of water-soluble aluminum in soils was found to be complexes with humic substances.

\section{Acknowledgements}

The present study was supported by Grants-in-Aid for Scientific Research from the Ministry of Education, Science and Culture (No. 07680554 and No. 10680501). The present study was supported by the Nippon Life Insurance Foundation.

\section{References}

1. B. I. Chevone and S. N. Linzon, Environ. Pollut., 1988, 50, 87.

2. S. E. Lindberg, M. Bredemeier, D. A. Schafer, and L. Qi, Atmos. Environ., 1990, 24, 2207.

3. M. Nashimoto and K. Takahashi, Shinrin Ritti (in Japanese), 1990, 32, 70

4. K. Takahashi, M. Nashimoto, and H. Ueta, Environ. Sci., 1991, 4, 51.

5. M. Nashimoto, K. Takahashi, and S. Ashihara, Environ. Sci., 1993, 6, 121.

6. E. Yamada, D. Yoshida, L.-C. Hu, and T. Yamada, Bunseki Kagaku, 1996, 12, 1083.

7. E. Yamada, M. Kimura, K. Tomozawa, and Y. Fuse, Environ. Sci. Technol., 1999, 33, 4141.

8. E. Yamada, M. Kimura, K. Tomozawa, and Y. Fuse, Bull.

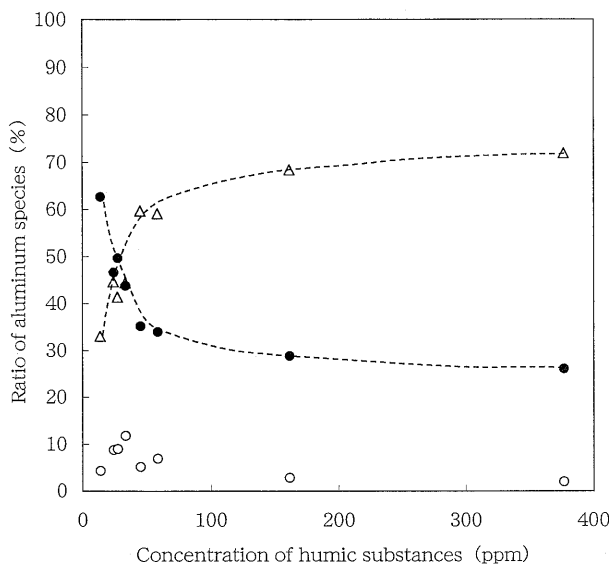

Fig. 13 Ratios of aluminum species in soil extracts as a function of the concentration of humic substances. $\mathrm{O}, \mathrm{Al}^{3+}$ and $\mathrm{Al}-\mathrm{OH}$ complex; -, aluminum organic complexes (cation species); $\triangle$, aluminum organic complexes (anion species)

Chem. Soc. Jpn., 2000, 73, 1291.

9. E. Yamada, K. Tomozawa, H. Nakanishi, and Y. Fuse, Bull. Chem. Soc. Jpn., in press.

10. T. Yamada, M. Ohno, M. Sato, and E. Yamada, Environ. Sci., 1996, 9, 211.

11. T. Yamada, M. Ohno, and E. Yamada, "Conference of the Environmental Science Society”, 1995, Abstr., 59.

12. C. T. Driscoll, J. P. Baker, and J. J. Bisogni, Nature [London], 1980, 284, 161.

13. S. Helliwell, G. E. Batley, T. M. Florence, and B. G. Lumsden, Environ. Tech. Lett., 1983, 4, 141.

14. Z. Rengel, New Phytol., 1992, 121, 499.

15. B. Ulrich, R. Mayer, and P. K. Khanna, Soil Sci., 1980, 130, 193.

16. S. Takatsu, K. Tsunoda, and E. Yoshimura, Bunseki, 1998 772 .

17. K. Tsunoda, T. Yagasaki, S. Aizawa, H. Akaiwa, and K. Satake, Anal. Sci., 1997, 13, 757.

18. S. H. Sutheimer and S. E. Cabaniss, Anal. Chim. Acta, 1995, 303, 211.

19. S. H. Sutheimer and S. E. Cabaniss, Anal. Chem., 1995, 67 , 2342.

20. K. Sato, T. Wakamatsu, and A. Takahashi, Jpn. J. Soil Sci. Plant Nutr., 2000, 71, 615.

21. E. Yamada, T. Ozaki, and M. Kimura, Anal. Sci., 1998, 14, 327.

22. A. Watanabe, K. Itoh, S. Arai, and S. Kuwatsuka, Soil Sci. Plant Nutr., 1994, 40, 601.

23. S.-C. Tam and J. G. Mccoll, Soil Sci. Soc. Am. J., 1991, 55, 1421. 